\title{
Effect of lipid sources on fatty acid profiles of meat from pasture- and feedlot-finished Nellore bulls
}

\author{
G. Fiorentini ${ }^{a}{ }^{*}$, M.O. Santana ${ }^{a}$, J.D. Messana ${ }^{a}$, A.L.S. Valente ${ }^{a}$, C.J. Härter ${ }^{a}$, C.H.S. Rabelo ${ }^{a}$, \\ R.P. Barbero ${ }^{a}$, D.P.D. Lanna ${ }^{\mathrm{b}}$, R.A. Reis ${ }^{\mathrm{a}, \mathrm{c}}$, T.T. Berchielli ${ }^{\mathrm{a}, \mathrm{c}}$ \\ a Department of Animal Science, UNESP - Univ Estadual Paulista/Campus Jaboticabal, Rod. Professor Paulo Donato Castellane, km 5, Rural, Jaboticabal, São Paulo CEP \\ 14884-900, Brazil \\ b Animal Science Department at Escola Superior de Agricultura "Luiz de Queiroz" (ESALQ/USP), Piracicaba 13418900, Brazil \\ ${ }^{\mathrm{c}}$ INCT/CA - UFV - Department of Animal Science, s/n-Campus Universitário, Av. Peter Henry Rolfs, Viçosa, Minas Gerais CEP 36570-000, Brazil.
}

\section{A R T I C L E I N F O}

\section{Keywords:}

CLA

Lipid sources

Longissimus muscle

Protected fat

Soybean grains

Subcutaneous fat

\begin{abstract}
A B S T R A C T
We aimed to compare the influence of two lipid sources (soybean grain [SG], and protected fat [PF, Lactoplus], based on soybean oil) with a control diet (no lipid supplementation) on the fatty acid (FA) profile (longissimus muscle and subcutaneous fat) of beef cattle finished on grazing pasture or at a feedlot. The study was arranged in a complete randomized design, using $2 \times 3$ factorial scheme that combined 2 finishing systems and 3 diets. Seventy-eight young Nellore bulls (323.8 $\pm 25.4 \mathrm{~kg}$ body weight [BW] and $21 \pm 3$ months of age) were divided at random into two finishing systems: 1 ) pasture-finishing and 2) feedlot-finishing. The diet containing PF increased CLA in the muscle $(P=0.0002)$. Pasture-finished bulls fed lipid-supplemented diets had significantly more $(P=<0.0001)$ subcutaneous saturated fatty acids and polyunsaturated fatty acids (PUFA) in muscle, whereas the PUFA concentration of PF-fed bulls was highest $(P=<0.0001)$ in subcutaneous fat. The highest $(P=0.0090)$ concentration of Omega-6 (n6) was observed in the muscle tissue of pasture-finished animals supplemented with SG. However, the lowest concentration $(P=0.0010)$ of n6 FAs in subcutaneous fat was more evident in pasture-finished animals receiving the control diet. The concentration of C20:5 $n 3$ (EPA) was significantly higher $(P=0.040)$ in the muscle tissue of animals receiving the control diet in pasture and deposition of EPA was greater $(P=0.0020)$ in the subcutaneous fat of pasture-finished animals. The highest concentrations $(P=<0.0001)$ of $\mathrm{n} 3$ were observed in the muscle tissue of pasture-finished animals. Animals receiving the control diet in both finishing systems had a lower $(P=0.0051)$ n6:n3 ratio in muscle tissue. By comparison, feedlot-finished animals showed a higher $(P<0.01)$ n6:n3 ratio in muscle tissue, and the highest $(P=0.0190)$ n6:n3 ratio in subcutaneous fat was observed in pasture- and feedlot-finished animals supplemented with PF compared to the control diet. The muscle and subcutaneous fat tissues of feedlot-finished bulls fed the control and SG diets had a significantly higher $(P<0.05) \Delta^{9}$-desaturase C16 index. The lowest $(P=0.0010)$ elongase concentrations were observed in the muscle tissue of PF-fed bulls, regardless of finishing system. Overall, bulls finished on grazing pasture had a more desirable FA composition.
\end{abstract}

\section{Introduction}

The worldwide health concern regarding the nutritional quality of foods is unceasing, since the choice of nutritionally appropriate food can cause reductions in the incidence of several diseases, such as cancer, atherosclerosis, and cardiovascular disease (Scollan et al., 2014). For this reason, consumers are seeking meat with a lower proportion of saturated fatty acids (SFA) and a higher quantity of polyunsaturated fatty acids (PUFA; Wood et al., 2003).

One factor that may alter the FA profile of meat is the biohydrogenation process, in which PUFAs are hydrogenated into SFAs by ruminal microorganisms (Jenkins, 1993). However, biohydrogenation may vary based on diet, and the use of protected fat (PF) or soybean grain (SG) can reduce ruminal biohydrogenation of unsaturated fatty

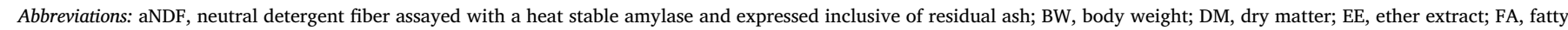

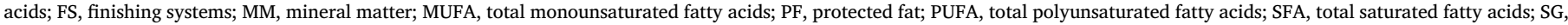
soybean grain; UFA, total unsaturated fatty acids; $n 3$, fatty acids of the omega-3 series; $n 6$, fatty acids of the omega- 6 series

* Correspondence address at: Departamento de Zootecnia, Faculdade de Ciências Agrárias e Veterinárias de Jaboticabal, Universidade Estadual Paulista “Júlio de Mesquita Filho", Rod. Professor Paulo Donato Castellane, km 5, Rural, Jaboticabal, São Paulo CEP 14884-900, Brazil.

E-mail addresses: giovanizoot@yahoo.com.br, fiorentini.giovani@gmail.com (G. Fiorentini).
} 
acids (UFA) due to ruminal protective processes (Fiorentini et al., 2015a; saponification process in PF, and the rigid outer layer in soybean grain), resulting in a greater deposition of UFAs in muscle tissue.

The increase in forage:concentrate ratio leads to higher concentrations of PUFA in the meat (French et al., 2000; Varela et al., 2004). In this context, Brazil is in a privileged position, because the beef production systems may be considered as "grass-fed-based": all breeding and rearing is carried out at pasture, and only 7.5\% (ABIEC, 2015) or less of the slaughtered cattle are finished in feedlots, usually for short periods of time (less than 100 days; Lobato et al., 2014).

Currently, Brazil is the world's second largest exporter of beef and is responsible for supplying meat to important international markets, such as in Europe and Asia (ABIEC, 2015). However, we are currently unaware of any studies that simultaneously compare the effect of finishing in tropical pastures and feedlots on the FA profiles of bovine meat in Brazil. Most information on the FA profile of meat and its influence on human health has been obtained from studies with high quantities of concentrate, based on finishing in feedlots (Oliveira et al., 2011; Oliveira et al., 2012; Fiorentini et al., 2015b) and temperate pastures (Realini et al., 2004; Gatellier et al., 2005; Freitas et al., 2014;). Thus, the objective of this study was to evaluate the lipid profile of longissimus muscle and subcutaneous fat from Nellore bulls reared in two finishing systems (grazing at pasture and in feedlot) and fed different lipid sources.

\section{Material and methods}

\subsection{Site, season, experimental conditions, and diets}

The protocol used in this experiment was in accordance with the guidelines of the Brazilian College of Animal Experimentation (COBEA-Colégio Brasileiro de Experimentação Animal) and was approved by the Ethics, Bioethics, and Animal Welfare Committee (CEBEA-Comissão de Ética e Bem Estar Animal) of the FCAVUNESP_Jaboticabal campus (protocol number 012799).

The assays were performed in the Foraging and Pastures Sector of the Animal Science Department, Faculty of Agricultural and Veterinary Sciences, Universidade Estadual Paulista in Jaboticabal, São Paulo, Brazil. The study was arranged in a complete randomized design, using $2 \times 3$ factorial scheme that combined 2 finishing systems and 3 diets. Seventy-eight young Nellore bulls $(323.8 \pm 25.4 \mathrm{~kg}$ body weight [BW] and $21 \pm 3$ months of age) were divided at random into two finishing systems: 1 ) pasture-finishing and 2) feedlot-finishing. Prior to the finishing systems the animals were pasture-fed on signal grass (Brachiaria brizantha cv. Xaraés) with supplementation of $0.6 \%$ of their BW. Three supplemental treatments were used: a control (no additional lipids), and SG or PF. These supplements were formulated to contain approximately $5.0 \%$ ether extract (EE). The supplementation used during the rearing phase was maintained throughout the study duration (the animals receiving SG in the rearing phase continued receiving SG regardless of their finishing systems). The finishing systems were carried out between May and October 2012.

All diets were formulated to meet the requirements of growing steers according to the NRC (2000). According to the manfacturer's description, the fat source in Lactoplus ${ }^{\circledast}$ (Dalquim group, Itajaí, Santa Catarina, Brazil) is protected from ruminal degradation, and is manufactured from saponified soybean oil, forming calcium salts of long chain fatty acids. The proportions of the contents were as follows: total fat $82.0 \%$ (min.), calcium $10 \%$ (max.), moisture 5.0\% (max.), and a net energy from lactation of $6.4 \mathrm{Mcal} / \mathrm{kg}$.

Forty-two animals were used in experiment 1 and were divided into 6 paddocks (two per treatment) composed of 1.9 ha of signal grass, totaling 7 animals per paddock and 14 animals per treatment. These animals were supplemented at a ratio of $1 \% \mathrm{BW}$ with one the following treatments: control (no addition of lipids), addition of SG, or addition of PF (i.e. Lactoplus ${ }^{\circledast}$ ). Supplements were supplied daily in covered troughs $(2.7 \mathrm{~m} \times 0.65 \mathrm{~m})$ at 08:00 $\mathrm{h}$. Supplements were formulated to achieve approximately $10 \%$ of the EE in dry matter (DM). The animals were allowed to adapt to their diet for 28 days and, after this period, were maintained under experimental conditions for 130 days. Intake estimate were evaluated during seven consecutive days in the intermediate phase of the experiment. To evaluate the individual intake of each animal a two marker technique was used as described by Santos et al. (2011), using LIPE $^{\circledR}$ and indigestible NDF (iNDF).

In feedlot-finished, 12 animals were used per treatment, totaling 36 animals. The animals were kept in individual pens measuring $8 \mathrm{~m}^{2}$ $(4 \times 2 \mathrm{~m})$ that contained concrete troughs and water dispensers. The animals were allowed to adapt to diet, facilities, and management for 28 days, and, after this period, were confined under experimental conditions for 114 days. The roughage used was corn silage and the concentrate was composed of corn, soybean meal, and urea (i.e. the control diet), in addition to one of two different lipid sources: SG or PF. The corn silage was produced from hybrid Impact Víptera (Syngenta, São Paulo, SP, Brazil), which had been harvested with 35\% DM. The process of filling and sealing the silo (surface) occurred on the same day, and the silo remained closed for 88 days.

The forage:concentrate ratio used in the feedlot-finished was 40:60. The diets were supplied once a day $(08: 00 \mathrm{~h})$ and the amount of feed offered was adjusted daily based on the amount consumed in previous days to keep the leftovers at around $10 \%$ of that supplied. Leftovers daily weights and samplings were performed for the diet quantities provided for each animal, and thus calculate the daily dry matter intake. The proportions of the ingredients in the concentrate, chemical composition, and lipid profile of diets used in pasture and feedlot finishing systems are shown in Tables 1 and 2, respectively.

\subsection{Slaughter of animals}

After the experimental period, the animals were transported to a

Table 1

Lipid ingredients ( $\mathrm{kg}$ ), chemical composition (\% of dry matter), and FA profiles ( $\mathrm{g} / 100 \mathrm{~g}$ total fatty acid, FA) of three diet treatments and forage grass used in the pasture finishing system.

\begin{tabular}{|c|c|c|c|c|}
\hline & \multicolumn{3}{|c|}{ Diets $^{1}$} & \multirow[t]{2}{*}{ Forage } \\
\hline & $\mathrm{CO}$ & SG & $\mathrm{PF}$ & \\
\hline \multicolumn{5}{|l|}{ Ingredients (kg) } \\
\hline Ground Corn & 83.5 & 65.9 & 76.9 & - \\
\hline Soybean Meal & 9.90 & 0.00 & 9.70 & - \\
\hline Soybean Grain & 0.00 & 28.6 & 0.00 & - \\
\hline Protected Fat & 0.00 & 0.00 & 6.6 & - \\
\hline Mineral Mix & 4.10 & 4.10 & 4.10 & - \\
\hline Urea & 2.50 & 1.40 & 2.70 & - \\
\hline \multicolumn{5}{|l|}{ Chemical Composition (kg/100 kg) } \\
\hline Dry Matter & 88.4 & 89.5 & 89.1 & 61.5 \\
\hline Organic Matter & 94.2 & 92.0 & 93.7 & 89.7 \\
\hline Crude Protein & 22.5 & 21.3 & 21.9 & 8.71 \\
\hline Ethereal Extract & 3.90 & 10.7 & 10.4 & 2.91 \\
\hline Neutral Detergent Fiber & 12.6 & 11.7 & 12.9 & 58.5 \\
\hline \multicolumn{5}{|c|}{ Fatty Acid Profile (g/100 g total FA) } \\
\hline C10:0 (Capric) & 0.00 & 0.00 & 0.00 & 0.36 \\
\hline C12:0 (Lauric) & 0.00 & 4.91 & 0.00 & 1.82 \\
\hline C14:0 (Myristic) & 0.14 & 0.04 & 0.02 & 1.31 \\
\hline C16:0 (Palmitic) & 10.4 & 2.81 & 2.52 & 30.6 \\
\hline C17:0 (Margaric) & 0.45 & 0.38 & 0.42 & 0.64 \\
\hline C18:0 (Stearic) & 3.68 & 14.63 & 6.21 & 3.63 \\
\hline C16:1 (Palmitoleic) & 0.12 & 0.14 & 0.12 & 0.15 \\
\hline C18:1 n9, cis (Oleic) & 21.9 & 44.9 & 23.7 & 4.33 \\
\hline C18:2 cis-9 cis-12 (Linoleic) & 48.9 & 25.6 & 54.3 & 15.2 \\
\hline C18:3 n6 (Linolenic) & 4.70 & 1.65 & 5.60 & 36.9 \\
\hline C20:0 (Arachidic) & 0.00 & 1.67 & 0.00 & 1.05 \\
\hline Unsaturated fatty acids & 77.4 & 79.6 & 80.1 & 57.3 \\
\hline Saturated fatty acids & 22.6 & 20.4 & 19.9 & 42.7 \\
\hline
\end{tabular}

${ }^{1} \mathrm{CO}=$ control; SG $=$ soybean grain; $\mathrm{PF}=$ protected fat. 
Table 2

Lipid ingredients $(\mathrm{kg})$, chemical composition (\% of dry matter), and FA profiles (g/100 g total FA) of three diet treatments used in the feedlot finishing system.

\begin{tabular}{|c|c|c|c|}
\hline & \multicolumn{3}{|c|}{ Diets $^{1}$} \\
\hline & $\mathrm{CO}$ & SG & $\mathrm{PF}$ \\
\hline \multicolumn{4}{|l|}{ Ingredients (kg) } \\
\hline Corn Silage & 40.0 & 40.0 & 40.0 \\
\hline Ground Corn & 49.2 & 47.5 & 47.4 \\
\hline Soybean Meal & 6.81 & 0.00 & 6.50 \\
\hline Soybean Grain & 0.00 & 8.50 & 0.00 \\
\hline Protected Fat & 0.00 & 0.00 & 2.1 \\
\hline Mineral Mix & 3.00 & 3.00 & 3.00 \\
\hline Urea & 0.99 & 0.99 & 0.99 \\
\hline \multicolumn{4}{|l|}{ Chemical Composition (kg/100 kg) } \\
\hline Dry Matter & 57.8 & 58.2 & 58.5 \\
\hline Organic Matter & 94.6 & 94.8 & 93.2 \\
\hline Crude Protein & 15.0 & 15.1 & 14.9 \\
\hline Ethereal Extract & 3.30 & 4.97 & 5.02 \\
\hline Neutral detergent fiber & 22.1 & 21.8 & 21.9 \\
\hline \multicolumn{4}{|c|}{ Fatty Acid Profile (g/100 g total FA) } \\
\hline C12:0 (Lauric) & 0.40 & 0.30 & 0.30 \\
\hline C14:0 (Myristic acid) & 0.40 & 0.40 & 0.40 \\
\hline C16:0 (Palmitic) & 19.5 & 18.1 & 17.5 \\
\hline C16:1 (Palmitoleic) & 0.10 & 0.10 & 0.10 \\
\hline C17:0 (Heptadecanoic) & 0.20 & 0.20 & 0.20 \\
\hline C18:0 (Stearic) & 2.80 & 3.12 & 2.95 \\
\hline C18:1 n9, cis (Oleic) & 31.4 & 44.3 & 28.2 \\
\hline C18:2 cis-9 cis-12 (Linoleic) & 42.3 & 29.1 & 43,6 \\
\hline C18:3 n6 (Linolenic) & 2.80 & 4.30 & 4.10 \\
\hline C20:0 (Arachidic) & 0.00 & 0.00 & 2.60 \\
\hline Unsaturated fatty acids & 78.3 & 78.6 & 78.1 \\
\hline Saturated fatty acids & 21.7 & 21.4 & 21.9 \\
\hline
\end{tabular}

${ }^{1} \mathrm{CO}=$ control; $\mathrm{SG}=$ soybean grain; $\mathrm{PF}=$ protected fat.

commercial abattoir. After being starved for $24 \mathrm{~h}$, the animals were stunned by cerebral concussion using a compressed air gun and then slaughtered by bleeding via sectioning of the jugular veins and carotid arteries. The right and left halves of each carcass were marked and separated in a cold chamber. After $24 \mathrm{~h}$ in the cold chamber, muscle tissue and subcutaneous fat sampling was conducted on the left half of each carcass. Approximately $2.5 \mathrm{~cm}$ thick samples were excised from the ribeye at the height of the 12th rib through a perpendicular cut to the longissimus muscles located between the 12th and 13th ribs. The samples were then vacuum-packed and cooled to evaluate the composition of FA in the longissimus muscles and in the subcutaneous fat. The Table 3 shows the values related to dry matter intake, performance, and chemical composition of longissimus muscle of Nellore bulls fed different lipid sources in feedlot and pasture finishing systems.

\subsection{Lipid extraction and calculations}

To determine the FA composition of the longissimus muscle and subcutaneous fat samples, transverse sections were collected from the longissimus muscles, freeze-dried, and frozen for lipid extraction and methylation. Subcutaneous fat was extracted using a chloroform-methanol mixture as reported by Bligh and Dyer (1959), and the fatty acid methyl esters (FAME) were obtained by the ISO 5509 method (Iso, 1978). Qualitative and quantitative measurements of the FA contents were performed by gas chromatography using a chromatograph (Model GC-14B with a Communication Bus Module 102; Shimadzu, Kyoto, Japan) with a flame ionization detector (FID) and fused silica capillary column (Omegawax ${ }^{\circledast}$ 250; Sigma-Aldrich Co. LLC., St. Louis, Missouri, USA). Helium was used as the carrier gas at a flow rate of $1 \mathrm{~mL} / \mathrm{min}$. A $1-\mu \mathrm{L}$ aliquot of the sample was injected into a "split" at a division ratio of $1: 100$ at $250{ }^{\circ} \mathrm{C}$. The oven was programmed to remain at $100{ }^{\circ} \mathrm{C}$ for $2 \mathrm{~min}$ and then increase temperature to $220^{\circ} \mathrm{C}$ at $4{ }^{\circ} \mathrm{C} / \mathrm{min}$ for $25 \mathrm{~min}$, while the detector was at $280^{\circ} \mathrm{C}$. Identification and quantification of the FAMEs were achieved by comparison with the retention times and concentrations of standard FAMEs.

The activity index for $\Delta^{9}$-desaturase enzymes were calculated which are responsible for the conversion of SFAs with 16 and 18 carbons into their respective monounsaturated forms with a double bond at carbon 9 as described by Malau-Aduli et al. (1997). The atherogenicity index was calculated as described by Ulbricht and Southgate (1991) as an indicator of the risk of cardiovascular disease. Calculations were performed using the following equations:

- $\Delta^{9}$-desaturase C16 activity $=100$ [(16:1 cis-9)/16:1 cis-9 + 16:0)].

- $\Delta^{9}$-desaturase C18 activity $=100[(18: 1$ cis-9)/18:1 cis-9 + 18:0)].

- Elongase activity $=100[(\mathrm{C} 18: 0+\mathrm{C} 18: 1 \mathrm{cis}-9) /(\mathrm{C} 16: 0+\mathrm{C} 16: 1$ cis$9+$ C18:0 + C18:1 cis-9)].

- Atherogenicity index $=[C 12: 0+4(C 14: 0)+C 16: 0] /(\Sigma S F A+\Sigma P U F A)$.

\subsection{Laboratory analysis}

Samples of corn silage, forage, and concentrates were evaluated for DM (method no. 934.01), mineral material (MM; method 942.05) and EE (method 954.02) according to the recommendations of the AOAC (1990). The nitrogen level was obtained by the Dumas combustion method, using an N-type FP-528 LC analyzer (LECO Co., St.

Table 3

Data on dry matter intake, performance, and chemical composition of longissimus muscle of Nellore bulls fed different lipid sources in feedlot and pasture finishing systems (FS).

\begin{tabular}{|c|c|c|c|c|c|c|c|c|c|c|}
\hline & \multicolumn{3}{|c|}{ Feedlot } & \multicolumn{3}{|c|}{ Pasture } & \multirow[t]{2}{*}{ SEM } & \multicolumn{3}{|l|}{ P-value } \\
\hline & $\mathrm{CO}$ & $\mathrm{PF}$ & SG & $\mathrm{CO}$ & $\mathrm{PF}$ & SG & & FS & Diet & Interaction \\
\hline Number of animals Variable, & 12 & 12 & 12 & 14 & 14 & 14 & - & - & - & - \\
\hline Dry matter intake, $\mathrm{kg} /$ day & $9.42^{\mathrm{a}}$ & $8.35^{\mathrm{b}}$ & $8.42^{\mathrm{b}}$ & $6.20^{\mathrm{c}}$ & $8.50^{\mathrm{b}}$ & $8.30^{\mathrm{b}}$ & 1.064 & 0.042 & 0.050 & 0.032 \\
\hline Initial weight, $\mathrm{kg}$ & 314 & 338 & 330 & 318 & 336 & 328 & 9.606 & 0.432 & 0.894 & 0.765 \\
\hline Average daily gain, $\mathrm{kg}$ /day & $1.26^{\mathrm{a}}$ & $1.33^{\mathrm{a}}$ & $1.34^{\mathrm{a}}$ & $0.62^{\mathrm{c}}$ & $1.02^{\mathrm{b}}$ & $0.93^{\mathrm{b}}$ & 0.283 & 0.021 & 0.049 & 0.044 \\
\hline Final weight, kg & $458^{\mathrm{A}}$ & $490^{\mathrm{A}}$ & $483^{\mathrm{A}}$ & $405^{\mathrm{B}}$ & $469^{\mathrm{B}}$ & $449^{\mathrm{B}}$ & 30.51 & 0.014 & 0.543 & 0.632 \\
\hline Hot carcass weight, $\mathrm{kg}$ & $256^{\mathrm{A}}$ & $278^{\mathrm{A}}$ & $267^{\mathrm{A}}$ & $230^{\mathrm{B}}$ & $268^{\mathrm{B}}$ & $254^{\mathrm{B}}$ & 16.62 & 0.044 & 0.765 & 0.432 \\
\hline Hot carcass yield, $\mathrm{kg} / 100 \mathrm{~kg}$ & 55.8 & 56.6 & 55.5 & 56.8 & 57.1 & 56.6 & 0.616 & 0.324 & 0.145 & 0.632 \\
\hline Subcutaneous fat thickness, mm & 3.71 & 4.28 & 3.48 & 3.01 & 3.97 & 3.34 & 0.455 & 0.123 & 0.245 & 0.542 \\
\hline Loin eye area, $\mathrm{cm}^{2}$ & $83.6^{\mathrm{A}}$ & $77.2^{\mathrm{A}}$ & $83.1^{\mathrm{A}}$ & $69.8^{\mathrm{B}}$ & $72.3^{\mathrm{B}}$ & $70.5^{\mathrm{B}}$ & 6.196 & 0.025 & 0.214 & 0.342 \\
\hline \multicolumn{11}{|l|}{ Chemical composition, g/100 g } \\
\hline Moisture & 70.7 & 70.5 & 70.3 & 70.6 & 70.3 & 70.7 & 0.183 & 0.645 & 0.783 & 0.812 \\
\hline Ashes & 1.38 & 1.28 & 1.40 & 1.40 & 1.30 & 1.35 & 0.052 & 0.435 & 0.313 & 0.489 \\
\hline Protein & 25.6 & 24.7 & 25.1 & 22.9 & 25.3 & 23.0 & 1.186 & 0.256 & 0.214 & 0.476 \\
\hline Ether Extract & 2.32 & 3.45 & 3.10 & 2.53 & 3.10 & 3.28 & 0.442 & 0.289 & 0.432 & 0.543 \\
\hline
\end{tabular}

$\mathrm{CO}=$ control diet; $\mathrm{PF}=$ diet with addition of protected fat; SG = diet with addition of soybean grain; SEM = standard error of mean.

Means followed by different lower and uppercase letters indicate significant differences within diets and between finishing systems, respectively $(P<0.05)$.

When there was interaction between diet and FS, only lowercase letters in the comparison between all diets were taken into account. 
Joseph, Michigan, USA). Neutral detergent fiber (aNDF) was determined using $\alpha$-amylase and without the addition of sodium sulfite following Van Soest et al. (1991) and adapted for the Ankom200 Fiber Analyzer (Ankom Technology, Fairport, NY).

To determine the FA composition of feed offerings, a sample of approximately $1 \mathrm{~g}$ was used. The frozen sample was homogenized in $20 \mathrm{~mL}$ of a chloroform and methanol solution (2:1) using a Turrax homogenizer, disintegrator, and emulsifier (Folch et al., 1957). Next, the lipid extract aliquot was methylated following the protocol in Kramer et al. (1997). Fatty acids were quantified using a GC 2010 gas chromatograph (Shimadzu Corp., Kyoto, Japan) with an SP-2560 capillary column $(100 \mathrm{~m} \mathrm{~L} \times 0.20 \mathrm{~mm} \mathrm{D}$ with a $0.02-\mu \mathrm{m}$ film thickness; Supelco, Bellefonte, Pennsylvania, USA). The initial temperature was set to $70{ }^{\circ} \mathrm{C}$ for $4 \mathrm{~min}$ and then raised by $13^{\circ} \mathrm{C} / \mathrm{min}$ until it reached $175^{\circ} \mathrm{C}$ and then held for $27 \mathrm{~min}$. The temperature was increased by $4{ }^{\circ} \mathrm{C} / \mathrm{min}$ until it reached $215^{\circ} \mathrm{C}$ and then held for $31 \mathrm{~min}$. Hydrogen was used as the carrier gas at a flow rate of $40 \mathrm{~cm}^{3} / \mathrm{s}$.

\subsection{Experimental design and statistical analysis}

The study was arranged in a complete randomized design, using $2 \times 3$ factorial scheme that combined 2 finishing systems and 3 diets. The data were subjected to analysis of variance (ANOVA) using the MIXED procedure in SAS software (version 9.4; SAS Institute Inc., Cary, North Carolina, USA), in which the diets (2 degrees of freedom [df]) and the finishing system ( $1 \mathrm{df}$ ) were considered as fixed effects, and the error was considered as a random effect. Treatment means were compared by least squares using the pdiff command with Fisher's exact test. Residual graphs were used to detect violations of the ANOVA assumptions, such as variance heterogeneity, auto-correlated error, and the presence of outliers. Statistical significance was established at $P<0.05$. The following general model was used:

$Y_{i j k}=\mu+D_{i}+F_{j}+D F_{i j}+e_{i j k}$

where $Y_{i j k}=$ response variable; $\mu=$ general mean; $D=$ effect of the diet $i ; F_{j}=$ effect of the finishing system; $D F=$ effect of interaction between the diet and finishing system; and $e_{i j k}=$ mean error.

\section{Results}

There was a significant interaction between supplementation with different lipid sources and finishing systems (feedlot and pasture; $P<0.05$ ), which resulted in changes in the dry matter intake and average daily gain. The highest values of the dry matter intake $(P=0.032)$ and average daily gain $(P=0.044)$ were observed in the feedlot-finished animals supplemented with CO (Table 3 ). Feedlot-finished animals showed significantly higher final weight $(P=0.014)$, hot carcass weight $(P=0.044)$, and loin eye area $(P=0.025)$ than animals finished in pasture (Table 3 ).

There was a significant interaction between supplementation with different lipid sources and finishing systems (feedlot and pasture; $P<0.05$ ), which resulted in changes in the concentration of saturated (C15:0 iso, C15:0, C17:0 iso, C17:0, C23:0), and unsaturated FA (C16:1 cis-9, C17:1, C18:1 cis-12, C18:1 cis-13, C18:1 cis-15, C18:2 cis-9 cis-12, C18:3 n6, C20:2, C20:3 n6, C20:3 n3, C20:4 n6; Table 4).

The muscle tissue of feedlot-finished animals fed PF, and supplemented in pasture with PF and SG presented a higher concentration of C18:1 cis-12 $(P=0.0020)$. However, muscle tissue of pasture-finished animals contained a lower concentration of C18:1 cis-13 regardless of lipid supplementation (Table 4 and 5). Animals supplemented with PF in pasture and at the feedlot showed a higher concentration of FA C18:1 cis-15 in muscle tissue and subcutaneous fat $(\mathrm{P}<0.05)$, as did pasturefinished animals receiving the control diet.

The greatest concentration of C18:2 cis-9 cis-12 ( $P=0.009), \mathrm{C} 20: 2$ $(P=0.0130)$, and $\mathrm{C} 20: 3 n 3(P=0.004)$ was observed in the muscle tissue of animals supplemented with PF and SG in pasture. Pasture- finished animals fed SG had a higher concentration of C20:3 n6 $(P=0.0015)$ and $\mathrm{C} 20: 4 n 6(P=0.009)$ in their muscle tissue. The muscle tissue of pasture-finished animals supplemented with SG had a higher concentration of C18:3 $n 6(P=0.0252)$, whereas in subcutaneous fat, animals receiving the control diet in pasture had the highest concentrations, which were not significantly different from animals supplemented with PF (Table 5). The concentration of C20:5 n3 (EPA) was significantly higher $(P=0.040)$ in the muscle tissue of animals receiving the control diet in pasture and deposition of EPA was greater $(P=0.002)$ in the subcutaneous fat of pasture-finished animals (Table 4 and 5).

Pasture- and feedlot-finished animals showed significantly higher concentrations $(P=<0.0001)$ of C18:1trans and lower concentrations $(P=0.0030)$ of $\mathrm{C} 18: 1$ cis-9 in muscle tissue due to $\mathrm{PF}$ consumption (Table 4). Moreover, the muscle tissue of pasture-finished animals had higher concentrations $(P=<0.0001)$ of C18:1 trans and lower concentrations $(P=<0.0001)$ of $\mathrm{C} 18: 1$ cis-9. Supplementation with $\mathrm{PF}$ also led to a higher concentration $(P<0.008)$ of C18:1 trans in the subcutaneous fat of pasture-finished animals and lower concentrations $(P=<0.0001)$ of $\mathrm{C} 18: 1$ cis-9 in that of feedlot-finished animals (Table 5).

The diet containing PF resulted in significantly lower concentrations $(P=<0.0001)$ of $\mathrm{C} 18: 1$ cis-11 and a higher concentration $(P<0.01)$ of $\mathrm{C} 18: 1$ trans-16 and C18:2 cis-9 trans-11 in the muscle tissue regardless of the finishing system (Table 4). The lowest concentrations $(P<0.01)$ of C22:5 $n 6$ (DPA) and C22:6 n3 (DHA) FAs were observed in the muscle tissue of pasture-finished animals fed the control diet and SG (Table 5).

The concentration of monounsaturated FAs (MUFA) were lower $(P=<0.0001)$ in the muscle tissue and subcutaneous fat from animals kept in pasture (Table 6). By contrast, animals fed diets supplemented with PF and SG had reduced $(P=0.0170)$ concentrations of MUFA in the muscle tissue, whereas in subcutaneous fat the lowest concentration $(P=0.0140)$ was observed in animals supplemented with PF; this concentration did not differ from that in animals receiving the control diet.

Pasture-finished animals that were supplemented with PF and SG showed higher concentrations $(P=0.020)$ of PUFA in the muscle tissue, whereas the subcutaneous fat of animals supplemented with PF showed higher concentrations $(P=0.025)$ of PUFA in pasture-finished animals (Table 6).

The lowest concentration $(P<0.01)$ of the FA cis 18 was observed in the muscle and subcutaneous fat tissues of pasture-finished animals whose diets were supplemented with PF, and the diet with PF resulted in lower $(P<0.05)$ deposition between the two systems (Table 6$)$. The FA trans18 displayed the lowest concentration $(P=<0.0001)$ in the muscle and subcutaneous fat tissues of feedlot-finished animals fed the control diet regardless of the finishing system (Table 6). However, subcutaneous fat also had a lower concentration $(P<0.01)$ of this FA in animals supplemented with SG.

The highest PUFA: SFA ratio $(P=0.040)$ was observed in the muscle tissue of pasture-finished animals supplemented with SG. By contrast, supplementation with PF in pasture- and feedlot-finished animals resulted in a higher $(P<0.01)$ PUFA:SFA ratio in subcutaneous fat (Table 6). The highest $(P=0.0090)$ concentration of Omega-6 (n6) was observed in the muscle tissue of pasture-finished animals supplemented with SG (Table 6). However, the lowest concentration $(P=0.0010)$ of $\mathrm{n} 6$ FAs in subcutaneous fat was more evident in pasture-finished animals receiving the control diet. The highest concentrations $(P=<0.0001)$ of $n 3$ were observed in the muscle tissue of pasture-finished animals. By contrast, concentrations of n3 in subcutaneous fat were not significantly different $(P>0.05)$ between diets or finishing systems.

Animals receiving the control diet in both finishing systems had a lower $(P=0.0084)$ n6:n3 ratio in muscle tissue (Table 6). By comparison, feedlot-finished animals showed a higher $(P=0.0051) \mathrm{n} 6: \mathrm{n} 3$ 
Table 4

Profile of FA ( $\mathrm{g} / 100 \mathrm{~g})$ in the longissimus muscle tissue of Nellore bulls fed different lipid sources in feedlot and pasture finishing systems (FS).

\begin{tabular}{|c|c|c|c|c|c|c|c|c|c|c|}
\hline & \multicolumn{3}{|l|}{ Feedlot } & \multicolumn{3}{|l|}{ Pasture } & \multirow[t]{2}{*}{ SEM } & \multicolumn{3}{|l|}{$P$-value } \\
\hline & $\mathrm{CO}$ & $\mathrm{PF}$ & SG & $\mathrm{CO}$ & $\mathrm{PF}$ & SG & & FS & Diet & Interaction \\
\hline Number of animals & 12 & 12 & 12 & 14 & 14 & 14 & - & - & - & - \\
\hline $\mathrm{C} 10: 0$ & $0.089^{\mathrm{a}, \mathrm{B}}$ & $0.067^{\mathrm{b}, \mathrm{B}}$ & $0.086^{\mathrm{a}, \mathrm{B}}$ & $0.106^{\mathrm{a}, \mathrm{A}}$ & $0.089^{\mathrm{b}, \mathrm{A}}$ & $0.122^{\mathrm{a}, \mathrm{A}}$ & 0.008 & 0.0058 & 0.0002 & 0.3840 \\
\hline C12:0 & $0.089^{\mathrm{B}}$ & $0.081^{\mathrm{B}}$ & $0.093^{\mathrm{B}}$ & $0.111^{\mathrm{A}}$ & $0.100^{\mathrm{A}}$ & $0.118^{\mathrm{A}}$ & 0.006 & 0.0001 & 0.0780 & 0.8951 \\
\hline C14:0 & $3.08^{\mathrm{A}}$ & $3.09^{\mathrm{A}}$ & $2.79^{\mathrm{A}}$ & $2.28^{\mathrm{B}}$ & $2.13^{\mathrm{B}}$ & $1.90^{\mathrm{B}}$ & 0.158 & $<0.0001$ & 0.0611 & 0.8774 \\
\hline $\mathrm{C} 15: 0$ iso & $0.125^{\mathrm{c}}$ & $0.115^{c}$ & $0.101^{\mathrm{c}}$ & $0.234^{\mathrm{a}}$ & $0.177^{\mathrm{b}}$ & $0.166^{\mathrm{b}}$ & 0.011 & $<0.0001$ & $<0.0001$ & 0.0470 \\
\hline $\mathrm{C} 15: 0$ anteiso & $0.186^{\mathrm{B}}$ & $0.162^{\mathrm{B}}$ & $0.147^{\mathrm{B}}$ & $0.354^{\mathrm{A}}$ & $0.290^{\mathrm{A}}$ & $0.368^{\mathrm{A}}$ & 0.019 & $<0.0001$ & 0.0680 & 0.0560 \\
\hline C14:1 cis-9 & $0.620^{\mathrm{A}}$ & $0.644^{\mathrm{A}}$ & $0.653^{\mathrm{A}}$ & $0.356^{\mathrm{B}}$ & $0.261^{\mathrm{B}}$ & $0.272^{\mathrm{B}}$ & 0.041 & $<0.0001$ & 0.6820 & 0.2710 \\
\hline $\mathrm{C} 15: 0$ & $0.293^{c}$ & $0.303^{\mathrm{c}}$ & $0.375^{\mathrm{b}}$ & $0.433^{\mathrm{a}}$ & $0.375^{\mathrm{b}}$ & $0.352^{\mathrm{b}}$ & 0.017 & $<0.0001$ & 0.1290 & 0.0440 \\
\hline $\mathrm{C} 16: 0$ iso & $0.166^{\mathrm{a}}$ & $0.153^{\mathrm{b}}$ & $0.144^{\mathrm{b}}$ & $0.188^{\mathrm{a}}$ & $0.145^{\mathrm{b}}$ & $0.134^{\mathrm{b}}$ & 0.009 & 0.8970 & 0.0005 & 0.1854 \\
\hline C16:0 & $24.4^{\mathrm{b}, \mathrm{A}}$ & $26.7^{\mathrm{a}, \mathrm{A}}$ & $24.2^{\mathrm{b}, \mathrm{A}}$ & $22.8^{\mathrm{b}, \mathrm{B}}$ & $23.3^{\mathrm{a}, \mathrm{B}}$ & $22.0^{\mathrm{b}, \mathrm{B}}$ & 0.791 & 0.0002 & 0.0390 & 0.4950 \\
\hline $\mathrm{C} 17: 0$ iso & $0.286^{c}$ & $0.299^{c}$ & $0.257^{\mathrm{c}}$ & $0.542^{\mathrm{a}}$ & $0.464^{\mathrm{b}}$ & $0.441^{\mathrm{b}}$ & 0.013 & $<0.0001$ & $<0.0001$ & 0.0020 \\
\hline C16:1 cis-9 & $2.67^{\mathrm{ab}}$ & $2.49^{\mathrm{b}}$ & $2.93^{\mathrm{a}}$ & $2.47^{\mathrm{b}}$ & $1.85^{\mathrm{c}}$ & $1.94^{\mathrm{c}}$ & 0.163 & $<0.0001$ & 0.0410 & 0.0420 \\
\hline $\mathrm{C} 17: 0$ & $0.804^{\mathrm{b}}$ & $0.813^{\mathrm{b}}$ & $0.810^{\mathrm{b}}$ & $0.938^{\mathrm{a}}$ & $0.878^{\mathrm{ab}}$ & $0.747^{\mathrm{b}}$ & 0.039 & 0.1550 & 0.0600 & 0.0400 \\
\hline C17:1 & $0.504^{\mathrm{a}}$ & $0.386^{\mathrm{b}}$ & $0.512^{\mathrm{a}}$ & $0.553^{\mathrm{a}}$ & $0.323^{\mathrm{b}}$ & $0.377^{\mathrm{b}}$ & 0.030 & 0.0430 & $<0.0001$ & 0.0103 \\
\hline C18:0 & $16.8^{\mathrm{B}}$ & $17.7^{\mathrm{B}}$ & $15.8^{\mathrm{B}}$ & $19.9^{\mathrm{A}}$ & $20.3^{\mathrm{A}}$ & $19.5^{\mathrm{A}}$ & 0.971 & 0.0002 & 0.3670 & 0.8470 \\
\hline C18:1 trans & $1.37^{\mathrm{b}, \mathrm{B}}$ & $2.52^{\mathrm{a}, \mathrm{B}}$ & $1.13^{\mathrm{c}, \mathrm{B}}$ & $2.46^{\mathrm{b}, \mathrm{A}}$ & $2.97^{\mathrm{a}, \mathrm{A}}$ & $1.69^{\mathrm{c}, \mathrm{A}}$ & 0.139 & $<0.0001$ & $<0.0001$ & 0.0800 \\
\hline C18:1 cis-9 & $35.0^{\mathrm{a}, \mathrm{A}}$ & $31.7^{\mathrm{b}, \mathrm{A}}$ & $35.6^{\mathrm{a}, \mathrm{A}}$ & $29.6^{\mathrm{a}, \mathrm{B}}$ & $25.0^{\mathrm{b}, \mathrm{B}}$ & $26.5^{\mathrm{a}, \mathrm{B}}$ & 1.214 & $<0.0001$ & 0.0030 & 0.4960 \\
\hline C18:1 cis-11 & $1.28^{\mathrm{a}}$ & $1.03^{\mathrm{b}}$ & $1.36^{\mathrm{a}}$ & $1.37^{\mathrm{a}}$ & $1.20^{\mathrm{b}}$ & $1.31^{\mathrm{a}}$ & 0.050 & 0.1090 & $<0.0001$ & 0.1100 \\
\hline C18:1 cis-12 & $0.07^{c}$ & $0.219^{\mathrm{a}}$ & $0.09^{c}$ & $0.149^{b}$ & $0.188^{\mathrm{a}}$ & $0.182^{\mathrm{a}}$ & 0.010 & 0.0020 & $<0.0001$ & 0.0020 \\
\hline C18:1 cis-13 & $0.289^{\mathrm{b}}$ & $0.254^{\mathrm{b}}$ & $0.389^{\mathrm{a}}$ & $0.127^{\mathrm{c}}$ & $0.121^{\mathrm{c}}$ & $0.129^{c}$ & 0.018 & $<0.0001$ & 0.0010 & 0.0030 \\
\hline C18:1 trans-16 & $0.127^{\mathrm{b}}$ & $0.199^{\mathrm{a}}$ & $0.132^{\mathrm{b}}$ & $0.177^{\mathrm{b}}$ & $0.190^{\mathrm{a}}$ & $0.154^{\mathrm{b}}$ & 0.014 & 0.0800 & 0.0010 & 0.1260 \\
\hline C18:1 cis-15 & $0.120^{\mathrm{b}}$ & $0.159^{\mathrm{a}}$ & $0.111^{\mathrm{b}}$ & $0.165^{\mathrm{a}}$ & $0.151^{\mathrm{a}}$ & $0.113^{\mathrm{b}}$ & 0.008 & 0.0800 & $<0.0001$ & 0.0100 \\
\hline C18:2 cis-9 cis-12 & $5.01^{\mathrm{b}}$ & $4.82^{\mathrm{b}}$ & $5.41^{\mathrm{b}}$ & $6.87^{\mathrm{b}}$ & $10.5^{\mathrm{a}}$ & $11.6^{\mathrm{a}}$ & 0.773 & $<0.0001$ & 0.0030 & 0.0090 \\
\hline $\mathrm{C} 18: 3 n 6$ & $0.024^{\mathrm{b}}$ & $0.017^{\mathrm{b}}$ & $0.022^{\mathrm{b}}$ & $0.022^{\mathrm{b}}$ & $0.018^{\mathrm{b}}$ & $0.036^{\mathrm{a}}$ & 0.002 & 0.0800 & 0.0009 & 0.0252 \\
\hline C20:0 & 0.09 & 0.09 & 0.08 & 0.09 & 0.07 & 0.07 & 0.007 & 0.0700 & 0.0900 & 0.2560 \\
\hline $\mathrm{C} 18: 3 n 3$ & $0.148^{\mathrm{B}}$ & $0.129^{\mathrm{B}}$ & $0.166^{\mathrm{B}}$ & $0.427^{\mathrm{A}}$ & 0.373 & $0.431^{\mathrm{A}}$ & 0.020 & $<0.0001$ & 0.1040 & 0.7530 \\
\hline C20:1 & $0.269^{\mathrm{B}}$ & $0.219^{\mathrm{B}}$ & $0.246^{\mathrm{B}}$ & $0.556^{\mathrm{A}}$ & $0.502^{\mathrm{A}}$ & $0.603^{\mathrm{A}}$ & 0.035 & $<0.0001$ & 0.1630 & 0.4880 \\
\hline C18:2 cis- 9 trans 11 & $0.351^{\mathrm{b}}$ & $0.473^{\mathrm{a}}$ & $0.343^{\mathrm{c}}$ & $0.443^{\mathrm{b}}$ & $0.451^{\mathrm{a}}$ & $0.316^{\mathrm{c}}$ & 0.029 & 0.5070 & 0.0002 & 0.0830 \\
\hline $\mathrm{C} 20: 2$ & $0.04^{\mathrm{b}}$ & $0.04^{\mathrm{b}}$ & $0.04^{\mathrm{b}}$ & $0.04^{\mathrm{b}}$ & $0.07^{\mathrm{a}}$ & $0.07^{\mathrm{a}}$ & 0.005 & 0.0005 & 0.0056 & 0.0130 \\
\hline C20:3 n6 & $0.233^{\mathrm{b}}$ & $0.182^{\mathrm{b}}$ & $0.267^{\mathrm{b}}$ & $0.276^{\mathrm{b}}$ & $0.313^{\mathrm{b}}$ & $0.641^{\mathrm{a}}$ & 0.040 & $<0.0001$ & $<0.0001$ & 0.0015 \\
\hline $\mathrm{C} 20: 3 \mathrm{n} 3$ & $0.94^{\mathrm{b}}$ & $0.38^{\mathrm{c}}$ & $0.44^{\mathrm{c}}$ & $1.018^{\mathrm{b}}$ & $1.52^{\mathrm{a}}$ & $1.2^{\mathrm{ab}}$ & 0.155 & $<0.0001$ & 0.5780 & 0.0040 \\
\hline C20:4 n6 & $1.21^{\mathrm{c}}$ & $0.929^{c}$ & $1.15^{\mathrm{c}}$ & $1.93^{\mathrm{b}}$ & $1.93^{\mathrm{b}}$ & $3.24^{\mathrm{a}}$ & 0.230 & $<0.0001$ & 0.0030 & 0.0090 \\
\hline $\mathrm{C} 23: 0$ & $0.017^{\mathrm{c}}$ & $0.017^{\mathrm{c}}$ & $0.017^{\mathrm{c}}$ & $0.052^{\mathrm{a}}$ & $0.032^{\mathrm{b}}$ & $0.035^{\mathrm{b}}$ & 0.003 & $<0.0001$ & 0.0300 & 0.0210 \\
\hline $\mathrm{C} 20: 5 n 3$ & $0.17^{\mathrm{c}}$ & $0.13^{\mathrm{c}}$ & $0.17^{\mathrm{c}}$ & $0.527^{\mathrm{a}}$ & $0.316^{\mathrm{b}}$ & $0.169^{c}$ & 0.040 & $<0.0001$ & 0.0030 & 0.0400 \\
\hline $\mathrm{C} 24: 1$ & $0.0003^{\mathrm{B}}$ & $0.0005^{\mathrm{B}}$ & $0.0007^{\mathrm{B}}$ & $0.001^{\mathrm{A}}$ & $0.002^{\mathrm{A}}$ & $0.001^{\mathrm{A}}$ & 0.0004 & 0.0020 & 0.4610 & 0.7340 \\
\hline $\mathrm{C} 22: 5 n 6$ & $0.453^{\mathrm{a}, \mathrm{B}}$ & $0.345^{\mathrm{b}, \mathrm{B}}$ & $0.465^{\mathrm{a}, \mathrm{B}}$ & $0.979^{\mathrm{a}, \mathrm{A}}$ & $0.759^{\mathrm{b}, \mathrm{A}}$ & $1.177^{\mathrm{a}, \mathrm{A}}$ & 0.070 & $<0.0001$ & 0.0010 & 0.1010 \\
\hline $\mathrm{C} 22: 6 n 3$ & $0.05^{\mathrm{a}, \mathrm{B}}$ & $0.04^{\mathrm{b}, \mathrm{B}}$ & $0.05^{\mathrm{a}, \mathrm{B}}$ & $0.100^{\mathrm{a}, \mathrm{A}}$ & $0.05^{\mathrm{b}, \mathrm{A}}$ & $0.09^{\mathrm{a}, \mathrm{A}}$ & 0.010 & 0.0002 & 0.0100 & 0.1470 \\
\hline
\end{tabular}

$\mathrm{CO}=$ control diet; PF = diet with addition of protected fat; SG = diet with addition of soybean grain; SEM = standard error of mean .

Means followed by different lower and uppercase letters indicate significant differences within diets and between finishing systems, respectively $(P<0.05)$.

When there was interaction between diet and FS, only lowercase letters in the comparison between all diets were taken into account.

ratio in muscle tissue, and the highest $(P=0.0190) \mathrm{n} 6: \mathrm{n} 3$ ratio in subcutaneous fat was observed in pasture- and feedlot-finished animals supplemented with PF compared to the control diet.

The index of $\Delta^{9}$-desaturase C16 enzymes involved in the metabolism of FAs in the muscle and subcutaneous fat tissues was lower $(P<0.05)$ in diets supplemented with PF, whereas the highest $(P=0.030)$ index in muscle tissue was observed in feedlot-finished animals (Table 7).

The C18 $\Delta^{9}$-desaturase index was higher $(P=<0.0001)$ in the muscle and subcutaneous fat tissues of feedlot-finished animals (Table 7). In addition, supplementation of feedlot animals with PF resulted in a lower $(P=0.040) \Delta^{9}$-desaturase C18 index, which did not differ between animals receiving the control diet.

Regardless of finishing system, the muscle tissue of animals supplemented with $\mathrm{PF}$ had the lowest $(P=0.0010)$ elongase activity (Table 7). The elongase activity in subcutaneous fat was not affected by $\operatorname{diet}(P>0.05)$. The highest $(P=<0.0001)$ atherogenicity index occurred in the muscle and subcutaneous fat tissues of feedlot animals. In addition, the muscle tissue of animals supplemented with SG had a reduced atherogenicity index $(P=0.030)$, which did not differ from animals supplemented with PF.

\section{Discussion}

The lipid addition in the beef cattle diets decreases more significantly the feed intake of those animals in feedlot than in pasture
(Fiorentini et al., 2014; Carvalho et al., 2016;). The decrease of feed intake affects animal performance (Mertens, 1994). In this regard, the lower dry matter intake observed in the animals fed with CO pasturefinished can be attributed to a physical limitation caused by the pastures fiber content. Consequently, carcass characteristics such as final weight, hot carcass weight, and loin eye area are directly dependent on dry matter intake and animal performance. Likewise, Zinn et al. (2000) and Hess et al. (2008) reported that the total dry matter intake is affected by supplementing 50 to $60 \mathrm{~g}$ of lipids per $\mathrm{kg}$ of DM offered. Therefore, it can be concluded that there is no single universal optimum amount of added dietary lipid that would be appropriate across all feed sources; the amount is variable and depends, among others, on the particular lipid source used, the type of animal studied (i.e. specie, breed, and sex), and the supply methods.

Supplementing animals with SG did not alter concentrations of conjugated linoleic acid (CLA) in subcutaneous fat. Conjugated linoleic acid is implicated in the slow release of triglycerides contained in grain, and higher biohydrogenation of CLA precursors is carried out by ruminal microorganisms (Coppock and Wilks, 1991). In addition, parts of the soybeans may have remained intact following ingestion and thus promoted the release of PUFA from the rumen, as these would be protected inside the cells. Another explanation is that animals fed with grain stimulate a greater formation of trans-10 18:1, which is not a precursor of endogenous CLA (Griinari and Bauman, 1999). By contrast, supplementation with PF increased the concentration of CLA in 
Profile of FA (g/100 g) in the subcutaneous fat of Nellore bulls fed different lipid sources in feedlot and pasture finishing systems (FS).

\begin{tabular}{|c|c|c|c|c|c|c|c|c|c|c|}
\hline & \multicolumn{3}{|l|}{ Feedlot } & \multicolumn{3}{|l|}{ Pasture } & \multirow[t]{2}{*}{ SEM } & \multicolumn{3}{|l|}{ P-value } \\
\hline & $\mathrm{CO}$ & $\mathrm{PF}$ & SG & $\mathrm{CO}$ & $\mathrm{PF}$ & SG & & FS & Diet & Interaction \\
\hline Number of animals & 12 & 12 & 12 & 14 & 14 & 14 & - & - & - & - \\
\hline $\mathrm{C} 10: 0$ & $0.061^{\mathrm{a}}$ & $0.052^{\mathrm{b}}$ & $0.056^{\mathrm{b}}$ & $0.068^{\mathrm{a}}$ & $0.055^{\mathrm{b}}$ & $0.056^{\mathrm{b}}$ & 0.004 & 0.3080 & 0.0280 & 0.7520 \\
\hline $\mathrm{C} 12: 0$ & $0.083^{\mathrm{B}}$ & $0.088^{\mathrm{B}}$ & $0.077^{\mathrm{B}}$ & $0.125^{\mathrm{A}}$ & $0.134^{\mathrm{A}}$ & $0.112^{\mathrm{A}}$ & 0.008 & $<0.0001$ & 0.1380 & 0.8000 \\
\hline C14:0 & 3.59 & 3.57 & 3.19 & 3.70 & 3.50 & 3.304 & 0.181 & 0.7460 & 0.1010 & 0.8530 \\
\hline $\mathrm{C} 15: 0$ iso & $0.213^{\mathrm{c}}$ & $0.198^{\mathrm{c}}$ & $0.180^{\mathrm{c}}$ & $0.532^{\mathrm{a}}$ & $0.403^{\mathrm{b}}$ & $0.407^{\mathrm{b}}$ & 0.015 & $<0.0001$ & $<0.0001$ & 0.0008 \\
\hline $\mathrm{C} 15: 0$ anteiso & $0.259^{\mathrm{c}}$ & $0.233^{\mathrm{c}}$ & $0.211^{\mathrm{c}}$ & $0.624^{\mathrm{a}}$ & $0.456^{\mathrm{b}}$ & $0.436^{\mathrm{b}}$ & 0.020 & $<0.0001$ & $<0.0001$ & 0.0005 \\
\hline C14:1 cis-9 & $1.16^{\mathrm{A}}$ & $1.16^{\mathrm{A}}$ & $1.17^{\mathrm{A}}$ & $0.915^{\mathrm{B}}$ & $0.751^{\mathrm{B}}$ & $0.881^{\mathrm{B}}$ & 0.080 & $<0.0001$ & 0.4920 & 0.5770 \\
\hline $\mathrm{C} 15: 0$ & $0.397^{c}$ & $0.405^{c}$ & $0.416^{\mathrm{c}}$ & $0.813^{\mathrm{a}}$ & $0.677^{\mathrm{b}}$ & $0.667^{\mathrm{b}}$ & 0.024 & $<0.0001$ & 0.0180 & 0.0030 \\
\hline $\mathrm{C} 16: 0$ iso & $0.296^{\mathrm{a}, \mathrm{B}}$ & $0.243^{\mathrm{b}, \mathrm{B}}$ & $0.201^{\mathrm{c}, \mathrm{B}}$ & $0.377^{\mathrm{a}, \mathrm{A}}$ & $0.287^{\mathrm{b}, \mathrm{A}}$ & $0.255^{\mathrm{c}, \mathrm{A}}$ & 0.016 & $<0.0001$ & $<0.0001$ & 0.4300 \\
\hline C16:0 & 23.3 & 24.3 & 22.6 & 23.0 & 23.2 & 23.2 & 0.605 & 0.5530 & 0.3250 & 0.3780 \\
\hline $\mathrm{C} 17: 0$ iso & $0.374^{\mathrm{c}}$ & $0.378^{\mathrm{c}}$ & $0.352^{\mathrm{c}}$ & $0.613^{\mathrm{a}}$ & $0.558^{\mathrm{b}}$ & $0.495^{\mathrm{b}}$ & 0.013 & $<0.0001$ & $<0.0001$ & 0.0020 \\
\hline C16:1 cis-9 & $4.02^{\mathrm{a}}$ & $3.74^{\mathrm{b}}$ & $4.03^{\mathrm{a}}$ & $4.22^{\mathrm{a}}$ & $3.31^{\mathrm{b}}$ & $4.15^{\mathrm{a}}$ & 0.145 & 0.7530 & 0.0001 & 0.0800 \\
\hline $\mathrm{C} 17: 0$ & $0.841^{b c}$ & $0.791^{\mathrm{c}}$ & $0.874^{\mathrm{bc}}$ & $1.12^{\mathrm{a}}$ & $0.944^{\mathrm{b}}$ & $0.901^{\mathrm{b}}$ & 0.034 & $<0.0001$ & 0.0020 & 0.0010 \\
\hline $\mathrm{C} 17: 1$ & $0.544^{\mathrm{a}}$ & $0.466^{\mathrm{b}}$ & $0.628^{\mathrm{a}}$ & $0.604^{\mathrm{a}}$ & $0.408^{\mathrm{b}}$ & $0.459^{\mathrm{b}}$ & 0.023 & 0.0050 & $<0.0001$ & $<0.0001$ \\
\hline $\mathrm{C} 18: 0$ & $15.0^{\mathrm{B}}$ & $14.3^{\mathrm{B}}$ & $13.3^{\mathrm{B}}$ & $19.3^{\mathrm{A}}$ & $20.1^{\mathrm{A}}$ & $19.9^{\mathrm{A}}$ & 0.732 & $<0.0001$ & 0.6870 & 0.2760 \\
\hline C18:1 trans & $1.99^{\mathrm{c}}$ & $4.29^{\mathrm{b}}$ & $1.78^{\mathrm{c}}$ & $4.13^{\mathrm{b}}$ & $5.56^{\mathrm{a}}$ & $2.63^{\mathrm{c}}$ & 0.205 & $<0.0001$ & $<0.0001$ & 0.0080 \\
\hline C18:1 cis-9 & $40.3^{\mathrm{b}, \mathrm{A}}$ & $36.7^{\mathrm{c}, \mathrm{A}}$ & $42.8^{\mathrm{a}, \mathrm{A}}$ & $32.6^{\mathrm{b}, \mathrm{B}}$ & $31.6^{\mathrm{c}, \mathrm{B}}$ & $34.6^{\mathrm{a}, \mathrm{B}}$ & 0.868 & $<0.0001$ & $<0.0001$ & 0.1460 \\
\hline C18:1 cis-11 & $1.88^{\mathrm{a}, \mathrm{A}}$ & $1.66^{\mathrm{b}, \mathrm{A}}$ & $1.95^{\mathrm{a}, \mathrm{A}}$ & $1.56^{\mathrm{a}, \mathrm{B}}$ & $1.34^{\mathrm{b}, \mathrm{B}}$ & $1.52^{\mathrm{a}, \mathrm{B}}$ & 0.083 & $<0.0001$ & 0.0090 & 0.7210 \\
\hline C18:1 cis-12 & $0.472^{\mathrm{c}}$ & $0.645^{\mathrm{a}}$ & $0.502^{\mathrm{b}}$ & $0.475^{c}$ & $0.481^{c}$ & $0.564^{\mathrm{b}}$ & 0.031 & 0.2120 & 0.0210 & 0.0020 \\
\hline C18:1 cis-13 & $0.439^{\mathrm{b}, \mathrm{A}}$ & $0.404^{\mathrm{b}, \mathrm{A}}$ & $0.551^{\mathrm{a}, \mathrm{A}}$ & $0.168^{\mathrm{c}, \mathrm{B}}$ & $0.165^{\mathrm{c}, \mathrm{B}}$ & $0.187^{\mathrm{c}, \mathrm{B}}$ & 0.030 & $<0.0001$ & 0.0200 & 0.1140 \\
\hline C18:1 cis-15 & $0.122^{\mathrm{b}}$ & $0.183^{\mathrm{a}}$ & $0.124^{\mathrm{b}}$ & $0.199^{\mathrm{a}}$ & $0.194^{\mathrm{a}}$ & $0.145^{\mathrm{b}}$ & 0.011 & $<0.0001$ & $<0.0001$ & 0.0050 \\
\hline C18:2 cis- 9 cis-12 & $1.80^{\mathrm{b}}$ & $1.92^{\mathrm{ab}}$ & $1.93^{\mathrm{ab}}$ & $1.20^{\mathrm{c}}$ & $2.09^{\mathrm{a}}$ & $1.82^{\mathrm{b}}$ & 0.099 & 0.0250 & $<0.0001$ & 0.0007 \\
\hline $\mathrm{C} 18: 3 n 6$ & $0.062^{\mathrm{a}, \mathrm{B}}$ & $0.06^{\mathrm{ab}, \mathrm{B}}$ & $0.044^{\mathrm{b}, \mathrm{B}}$ & $0.08^{\mathrm{a}, \mathrm{A}}$ & $0.07^{\mathrm{ab}, \mathrm{A}}$ & $0.067^{\text {b.A }}$ & 0.006 & 0.0007 & 0.0200 & 0.5070 \\
\hline C20:0 & $0.002^{\mathrm{B}}$ & $0.001^{\mathrm{B}}$ & $0.001^{\mathrm{B}}$ & $0.003^{\mathrm{A}}$ & $0.003^{\mathrm{A}}$ & $0.004^{\mathrm{A}}$ & 0.0004 & $<0.0001$ & 0.7260 & 0.2500 \\
\hline $\mathrm{C} 18: 3 n 3$ & 0.163 & 0.166 & 0.177 & 0.164 & 0.192 & 0.174 & 0.008 & 0.2400 & 0.1800 & 0.1700 \\
\hline C20:1 & 0.218 & 0.205 & 0.217 & 0.226 & 0.247 & 0.234 & 0.011 & 0.0100 & 0.8970 & 0.2660 \\
\hline C18:2 cis- 9 trans -11 & $0.618^{\mathrm{b}}$ & $0.919^{\mathrm{a}}$ & $0.684^{\mathrm{b}}$ & $0.924^{\mathrm{a}}$ & $0.966^{\mathrm{a}}$ & $0.667^{\mathrm{b}}$ & 0.040 & 0.0020 & $<0.0001$ & 0.0006 \\
\hline $\mathrm{C} 20: 2$ & $0.011^{\mathrm{A}}$ & $0.013^{\mathrm{A}}$ & $0.016^{\mathrm{A}}$ & $0.009^{\mathrm{B}}$ & $0.011^{\mathrm{B}}$ & $0.007^{\mathrm{B}}$ & 0.002 & 0.0110 & 0.5780 & 0.2230 \\
\hline C20:3 n6 & $0.007^{\mathrm{B}}$ & $0.005^{\mathrm{B}}$ & $0.006^{\mathrm{B}}$ & $0.012^{\mathrm{A}}$ & $0.017^{\mathrm{A}}$ & $0.011^{\mathrm{A}}$ & 0.002 & $<0.0001$ & 0.5660 & 0.1760 \\
\hline C20:3 n3 & 0.002 & 0.002 & 0.002 & 0.002 & 0.0015 & 0.0015 & 0.004 & 0.1430 & 0.9050 & 0.7370 \\
\hline C20:4 n6 & 0.0003 & 0.0002 & 0.0003 & 0.0005 & 0.0005 & 0.0006 & 0.0002 & 0.0900 & 0.8180 & 0.9900 \\
\hline $\mathrm{C} 23: 0$ & $0.003^{\mathrm{a}, \mathrm{B}}$ & $0.002^{\mathrm{ab}, \mathrm{B}}$ & $0.001^{\mathrm{b}, \mathrm{B}}$ & $0.01^{\mathrm{a}, \mathrm{A}}$ & $0.008^{\mathrm{ab}, \mathrm{A}}$ & $0.006^{\mathrm{b}, \mathrm{A}}$ & 0.0007 & $<0.0001$ & 0.0020 & 0.2870 \\
\hline $\mathrm{C} 20: 5 n 3$ & $0.0006^{\mathrm{B}}$ & $0.0006^{\mathrm{B}}$ & $0.0012^{\mathrm{B}}$ & $0.004^{\mathrm{A}}$ & $0.002^{\mathrm{A}}$ & $0.002^{\mathrm{A}}$ & 0.0008 & 0.0020 & 0.5830 & 0.4230 \\
\hline $\mathrm{C} 24: 0$ & $0.007^{\mathrm{a}, \mathrm{B}}$ & $0.006^{\mathrm{ab}, \mathrm{B}}$ & $0.005^{\mathrm{b}, \mathrm{B}}$ & $0.02^{\mathrm{a}, \mathrm{A}}$ & $0.02^{\mathrm{ab}, \mathrm{A}}$ & $0.01^{\mathrm{b}, \mathrm{A}}$ & 0.001 & $<0.0001$ & 0.0060 & 0.1310 \\
\hline $\mathrm{C} 24: 1$ & $0.0004^{\mathrm{B}}$ & $0.0006^{\mathrm{B}}$ & $0.0004^{\mathrm{B}}$ & $0.002^{\mathrm{A}}$ & $0.001^{\mathrm{A}}$ & $0.001^{\mathrm{A}}$ & 0.0003 & 0.0010 & 0.6750 & 0.3670 \\
\hline $\mathrm{C} 22: 5 n 6$ & $0.015^{\mathrm{B}}$ & $0.014^{\mathrm{B}}$ & $0.01^{\mathrm{B}}$ & $0.03^{\mathrm{A}}$ & $0.03^{\mathrm{A}}$ & $0.04^{\mathrm{A}}$ & 0.004 & $<0.0001$ & 0.7100 & 0.1140 \\
\hline $\mathrm{C} 22: 6 n 3$ & $0.0004^{\mathrm{B}}$ & $0.0004^{\mathrm{B}}$ & $0.0003^{\mathrm{B}}$ & $0.0009^{\mathrm{A}}$ & $0.0009^{\mathrm{A}}$ & $0.0006^{\mathrm{A}}$ & 0.0002 & 0.0300 & 0.6580 & 0.9370 \\
\hline
\end{tabular}

$\mathrm{CO}=$ control diet; PF = diet with addition of protected fat; SG = diet with addition of soybean grain; SEM = standard error of mean .

Means followed by different lower and uppercase letters indicate significant differences within diets and between finishing systems, respectively $(P<0.05)$.

When there was interaction between diet and FS, only lowercase letters in the comparison between all diets were taken into account.

the muscle tissue of animals regardless of finishing system. This result must be related to the lower degradation of the lipid source (FA precursors of CLA) added to the supplement.

Feedlot-finished animals showed higher concentrations of C18:1 $n 9$,cis than pasture-finished animals, which is probably explained by the high concentration in certain products, such as corn and soybean meal, that are widely used in Brazilian feedlots (Millen et al., 2009). This statement corroborates the results obtained in this study (Tables 1-3) in which feedlot animals consumed more grains than the pasture-finished animals. The FA C18:1 n9,cis was the most abundant MUFA in meat from pasture- and feedlot-finished animals. Monounsaturated fats have been associated with a reduction of triglyceride levels in total cholesterol and LDL-c ("bad cholesterol"), and increasing levels of HDL-c ("good cholesterol") in blood plasma, which is important for reducing cardiovascular disease (Santos et al., 2013). However, in the body, C18:0 is immediately transformed into C18:1 n9,cis (French et al., 2003), as observed in the meat of pasture-finished animals, which had high concentrations of this FA.

Our results showed that the concentration of CLA in the subcutaneous fat of pasture-finished animals was up to 1.5 times higher than in feedlot-finished animals. This result is due to the primary consumption of green fodder rich in C18:2 cis-9 cis-12 and C18:3 n6 FAs (Marmer et al., 1984), which are precursors of CLA; in some cases, ruminants reared in extensive farming systems tended to have up to 6.5 times more CLA in their subcutaneous fat (Poulson et al., 2004).
Biohydrogenation can be inhibited by the decrease of ruminal $\mathrm{pH}$ (Demeyer and Doreau, 1999). The decrease in the $\mathrm{pH}$ values, normally associated to diets with the presence of concentrated, reduces lipolysis, an essential step for the occurrence of biohydrogenation. Thus, it is likely that the ruminal $\mathrm{pH}$ of animals feedlot-finished was lower than pasture-finished, which could also reduce the population of cellulolytic bacteria, which are involved mainly in the isomerization of linoleic acid to CLA (Harfoot and Hazlewood, 1997). Moreover, ruminal environment with higher $\mathrm{pH}$ favors the growth of Butyrivibrio fibrisolvens, which is also involved in the formation of CLA (Pariza et al., 2001); therefore, the ruminal environment is favorable to the growth of these microorganisms associated with biohydrogenation processes. Pasture-finished animals also had higher concentrations of n-3 PUFA, a finding in agreement with previous studies that compared finishing systems. These same studies also showed higher concentrations of n-3 PUFA in animals consuming greater amounts of forage (Realini et al., 2004; Scollan et al., 2014).

The concentration of C18:0 increased in pasture-finished animals probably due to the increased consumption and biohydrogenation of PUFA, which resulted in meat of higher nutritional content, since other SFAs (e.g. C12:0, C14:0, and C16:0) contribute to hypercholesterolemic effects, whereas C18:0 has no effect on blood cholesterol levels (French et al., 2003). The FA chains with less than 12 carbon atoms are, in general, elongated before being incorporated into the tissue by elongase, which explains the low C12:0 content in the meat. 
Table 6

Proportion of FA ( $\mathrm{g} / 100 \mathrm{~g}$ ) in the longissimus muscle and subcutaneous fat tissues of Nellore bulls fed different lipid sources in feedlot and pasture finishing systems (FS).

\begin{tabular}{|c|c|c|c|c|c|c|c|c|c|c|}
\hline & \multicolumn{3}{|l|}{ Feedlot } & \multicolumn{3}{|l|}{ Pasture } & \multirow[t]{2}{*}{ SEM } & \multicolumn{3}{|l|}{ P-value } \\
\hline & $\mathrm{CO}$ & $\mathrm{PF}$ & SG & $\mathrm{CO}$ & $\mathrm{PF}$ & SG & & FS & Diet & Interaction \\
\hline Number of animals & 12 & 12 & 12 & 14 & 14 & 14 & - & - & - & - \\
\hline \multicolumn{11}{|l|}{ Longissimus muscle } \\
\hline SFA & 47.1 & 51.1 & 46.8 & 48.3 & 49.7 & 47.0 & 1.850 & 0.8560 & 0.1770 & 0.7320 \\
\hline MUFA & $43.9^{\mathrm{a}, \mathrm{A}}$ & $40.6^{\mathrm{b}, \mathrm{A}}$ & $43.8^{\mathrm{b}, \mathrm{A}}$ & $38.4^{\mathrm{a}, \mathrm{B}}$ & $33.3^{\mathrm{b}, \mathrm{B}}$ & $33.4^{\mathrm{b}, \mathrm{B}}$ & 1.540 & $<0.0001$ & 0.0170 & 0.2630 \\
\hline PUFA & $8.98^{c}$ & $8.26^{c}$ & $9.40^{\mathrm{c}}$ & $13.3^{\mathrm{b}}$ & $17.0^{\mathrm{a}}$ & $19.6^{\mathrm{a}}$ & 1.240 & $<0.0001$ & 0.0100 & 0.0200 \\
\hline FA $\operatorname{Cis} 18$ & $42.8^{\mathrm{ab}, \mathrm{A}}$ & $39.1^{\mathrm{b}, \mathrm{A}}$ & $44.0^{\mathrm{a}, \mathrm{A}}$ & $38.3^{\mathrm{ab}, \mathrm{B}}$ & $38.9^{\mathrm{b}, \mathrm{B}}$ & $40.7^{\mathrm{a}, \mathrm{B}}$ & 1.210 & 0.0070 & 0.0200 & 0.1790 \\
\hline FA Trans 18 & $6.09^{\mathrm{b}, \mathrm{B}}$ & $8.19^{\mathrm{a}, \mathrm{B}}$ & $7.01^{\mathrm{a}, \mathrm{B}}$ & $9.96^{\mathrm{b}, \mathrm{A}}$ & $13.7^{\mathrm{a}, \mathrm{A}}$ & $13.8^{\mathrm{a}, \mathrm{A}}$ & 0.665 & $<0.0001$ & $<0.0001$ & 0.0850 \\
\hline PUFA:SFA & $0.19^{c}$ & $0.16^{\mathrm{c}}$ & $0.20^{\mathrm{c}}$ & $0.27^{\mathrm{b}}$ & $0.34^{\mathrm{b}}$ & $0.42^{\mathrm{a}}$ & 0.030 & $<0.0001$ & 0.0300 & 0.0400 \\
\hline n6 & $6.47^{\mathrm{c}}$ & $5.95^{c}$ & $6.85^{c}$ & $9.09^{c}$ & $12.8^{\mathrm{b}}$ & $15.5^{\mathrm{a}}$ & 1.030 & $<0.0001$ & 0.0040 & 0.0090 \\
\hline n3 & $1.31^{\mathrm{B}}$ & $0.678^{\mathrm{B}}$ & $0.995^{\mathrm{B}}$ & $2.04^{\mathrm{A}}$ & $2.33^{\mathrm{A}}$ & $2.43^{\mathrm{A}}$ & 0.191 & $<0.0001$ & 0.5147 & 0.0600 \\
\hline n6:n3 & $5.42^{\mathrm{b}, \mathrm{A}}$ & $10.2^{\mathrm{a}, \mathrm{A}}$ & $8.39^{\mathrm{a}, \mathrm{A}}$ & $4.37^{\mathrm{b}, \mathrm{B}}$ & $6.28^{\mathrm{a}, \mathrm{B}}$ & $6.53^{\mathrm{a}, \mathrm{B}}$ & 1.110 & 0.0051 & 0.0084 & 0.3670 \\
\hline \multicolumn{11}{|l|}{ Subcutaneous fat } \\
\hline SFA & $44.9^{\mathrm{B}}$ & $45.9^{\mathrm{B}}$ & $42.0^{\mathrm{B}}$ & $50.8^{\mathrm{A}}$ & $50.9^{\mathrm{A}}$ & $50.4^{\mathrm{A}}$ & 1.010 & $<0.0001$ & 0.0830 & 0.2090 \\
\hline MUFA & $51.9^{\mathrm{ab}, \mathrm{A}}$ & $50.3^{\mathrm{b}, \mathrm{A}}$ & $54.6^{\mathrm{a}, \mathrm{A}}$ & $46.1^{\mathrm{ab}, \mathrm{B}}$ & $45.1^{\mathrm{b}, \mathrm{B}}$ & $46.3^{\mathrm{a}, \mathrm{B}}$ & 0.974 & $<0.0001$ & 0.0140 & 0.2280 \\
\hline PUFA & $3,20^{\mathrm{c}}$ & $3.80^{\mathrm{b}}$ & $3.40^{\mathrm{bc}}$ & $3.10^{\mathrm{c}}$ & $4.00^{\mathrm{a}}$ & $3.30^{\mathrm{bc}}$ & 0.106 & 0.9030 & $<0.0001$ & 0.0250 \\
\hline FA Cis 18 & $45.0^{\mathrm{b}, \mathrm{A}}$ & $41.5^{\mathrm{c}, \mathrm{A}}$ & $48.7^{\mathrm{a}, \mathrm{A}}$ & $36.2^{\mathrm{b}, \mathrm{B}}$ & $35.9^{\mathrm{c}, \mathrm{B}}$ & $38.8^{\mathrm{a}, \mathrm{B}}$ & 0.921 & $<0.0001$ & $<0.0001$ & 0.0600 \\
\hline FA Trans 18 & $4.61^{\mathrm{b}, \mathrm{B}}$ & $7.45^{\mathrm{a}, \mathrm{B}}$ & $4.62^{\mathrm{b}, \mathrm{B}}$ & $6.54^{\mathrm{b}, \mathrm{A}}$ & $9.03^{\mathrm{a}, \mathrm{A}}$ & $5.50^{\mathrm{b}, \mathrm{A}}$ & 0.287 & $<0.0001$ & $<0.0001$ & 0.1620 \\
\hline PUFA:SFA & $0.071^{\text {b.A }}$ & $0.080^{\mathrm{a} . \mathrm{A}}$ & $0.080^{\mathrm{a} . \mathrm{A}}$ & $0.060^{\text {b.B }}$ & $0.078^{\mathrm{a.B}}$ & $0.065^{\mathrm{b} . \mathrm{B}}$ & 0.002 & $<0.0001$ & 0.0003 & 0.0800 \\
\hline n6 & $1.87^{\mathrm{b}}$ & $1.99^{\mathrm{ab}}$ & $1.98^{\mathrm{ab}}$ & $1.31^{\mathrm{c}}$ & $2.18^{\mathrm{a}}$ & $1.89^{\mathrm{b}}$ & 0.101 & 0.0700 & $<0.0001$ & 0.0010 \\
\hline n3 & 0.166 & 0.169 & 0.181 & 0.171 & 0.196 & 0.181 & 0.008 & 0.1340 & 0.2180 & 0.2090 \\
\hline $\mathrm{n} 6: \mathrm{n} 3$ & $11.2^{\mathrm{b}}$ & $12.0^{\mathrm{a}}$ & $10.7^{\mathrm{ab}}$ & $7.81^{b}$ & $11.2^{\mathrm{a}}$ & $10.7^{\mathrm{ab}}$ & 0.730 & 0.0190 & 0.0660 & 0.0600 \\
\hline
\end{tabular}

$\mathrm{CO}=$ control diet; $\mathrm{PF}=$ diet with addition of protected fat; $\mathrm{SG}=$ diet with addition of soybean grain.

Means followed by different lower and uppercase letters indicate significant differences within diets and between finishing systems, respectively $(P<0.05)$.

When there was interaction between diet and FS, only lowercase letters in the comparison between all diets were taken into account.

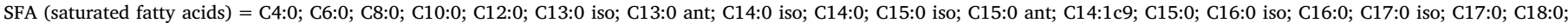
C20:0; C22:0; C24:0.

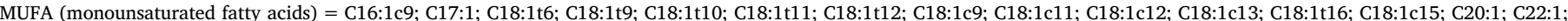
C24:1.

PUFA (polyunsaturated fatty acids) = C18:2t11c15; C18:2c9c12; C18:3; C18:2c9t11; C20:3; C20:4; C22:2; C20:5; C22:5; C22:6.

Total fatty acids cis18 = C18:1c9; C18:1c11; C18:1c12; C18:1c13; C18:1c15; C18:2t11c15; C18:2c9c12.

Total fatty acids trans18 = C18:1t9, C18:1t10; C18:1t11; C18:1t12; C18:1t16; C18:1t18; C18:2t11c15; C18:2c9c12.

n6 fatty acids (omega-6) $=\mathrm{C} 18: 3 \mathrm{n} 6+\mathrm{C} 20: 3 \mathrm{n} 6+\mathrm{C} 18: 2 \mathrm{c} 9 \mathrm{c} 12+\mathrm{C} 18: 2 \mathrm{t} 11 \mathrm{c} 15$.

$\mathrm{n} 3$ fatty acids (omega-3) $=\mathrm{C} 18: 3 \mathrm{n} 3+\mathrm{C} 20: 3 \mathrm{n} 3+\mathrm{C} 20: 5 \mathrm{n} 3$.

Nevertheless, a high intake of C12:0 can raise the levels of the SFAs C14:0 and C16:0 (Santos et al., 2013) and may result in a lower concentration of PUFA and, consequently, higher indices of atherogenicity in subcutaneous fat than observed in muscle tissue. However, this effect is not desirable due to the negative influence on human health associated with these indices. The highest elongase activity found in Nellore cattle can be explained by the lower levels of $\mathrm{C} 16: 0$ and $\mathrm{C} 16: 1$, and the higher levels of C18:1 $n 9$,c found in this genetic group compared to other breeds, which proves that the Nellore breed increases the biosynthesis of FAs, especially C18:1 $n$ 9,cis (Lopes et al., 2012).

Diets with high levels of concentrate reduce the rate of biohydrogenation by causing a reduction and maintenance of low ruminal $\mathrm{pH}$ values. Thus, inhibition of the activity and growth of the main bacteria involved in the lipolysis, isomerization, and biohydrogenation of FA in

Table 7

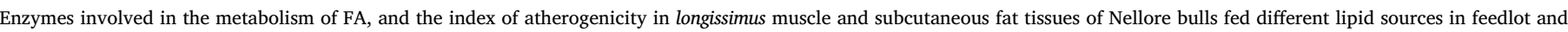
pasture finishing systems (FS).

\begin{tabular}{|c|c|c|c|c|c|c|c|c|c|c|}
\hline \multirow[t]{2}{*}{ Fatty Acid } & \multicolumn{3}{|l|}{ Feedlot } & \multicolumn{3}{|l|}{ Pasture } & \multirow[t]{2}{*}{ SEM } & \multicolumn{3}{|l|}{ P-value } \\
\hline & $\mathrm{CO}$ & $\mathrm{PF}$ & SG & $\mathrm{CO}$ & $\mathrm{PF}$ & SG & & FS & Diet & Interaction \\
\hline Number of animals & 12 & 12 & 12 & 14 & 14 & 14 & - & - & - & - \\
\hline \multicolumn{11}{|l|}{ Longissimus muscle } \\
\hline$\Delta^{9}$-desaturase C16 & $9.82^{\mathrm{a}, \mathrm{A}}$ & $8.53^{\mathrm{b}, \mathrm{A}}$ & $10.4^{\mathrm{a}, \mathrm{A}}$ & $9.77^{\mathrm{a}, \mathrm{B}}$ & $7.43^{\mathrm{b}, \mathrm{B}}$ & $8.13^{\mathrm{a}, \mathrm{B}}$ & 0.666 & 0.0300 & 0.0170 & 0.2130 \\
\hline$\Delta^{9}$-desaturase C18 & $68.1^{\mathrm{a}, \mathrm{A}}$ & $64.0^{\mathrm{b}, \mathrm{A}}$ & $69.1^{\mathrm{a}, \mathrm{A}}$ & $59.8^{\mathrm{a}, \mathrm{B}}$ & $54.3^{\mathrm{b}, \mathrm{B}}$ & $58.2^{\mathrm{a}, \mathrm{B}}$ & 2.050 & $<0.0001$ & 0.0400 & 0.8210 \\
\hline Elongase & $66.2^{\mathrm{a}}$ & $63.0^{\mathrm{b}}$ & $65.6^{\mathrm{a}}$ & $66.3^{\mathrm{a}}$ & $64.7^{\mathrm{b}}$ & $66.1^{\mathrm{a}}$ & 0.719 & 0.1660 & 0.0010 & 0.4680 \\
\hline Atherogenicity & $0.693^{\mathrm{a}, \mathrm{A}}$ & $0.692^{\mathrm{ab}, \mathrm{A}}$ & $0.673^{\mathrm{b}, \mathrm{A}}$ & $0.529^{\mathrm{a}, \mathrm{B}}$ & $0.481^{\mathrm{ab}, \mathrm{B}}$ & $0.451^{\mathrm{b}, \mathrm{B}}$ & 0.018 & $<0.0001$ & 0.0300 & 0.2450 \\
\hline \multicolumn{11}{|l|}{ Subcutaneous fat } \\
\hline$\Delta^{9}$-desaturase C16 & $14.7^{\mathrm{a}}$ & $13.2^{\mathrm{b}}$ & $15.1^{\mathrm{a}}$ & $15.9^{\mathrm{a}}$ & $12.5^{\mathrm{b}}$ & $15.2^{\mathrm{a}}$ & 0.565 & 0.6610 & $<0.0001$ & 0.2400 \\
\hline$\Delta^{9}$-desaturase C18 & $72.9^{\mathrm{ab}, \mathrm{A}}$ & $71.8^{\mathrm{b}, \mathrm{A}}$ & $76.2^{\mathrm{a}, \mathrm{A}}$ & $62.9^{\mathrm{c}, \mathrm{B}}$ & $61.2^{\mathrm{c}, \mathrm{B}}$ & $63.5^{\mathrm{c}, \mathrm{B}}$ & 1.320 & $<0.0001$ & 0.0360 & 0.5340 \\
\hline Elongase & 66.9 & 64.0 & 67.8 & 65.5 & 66.1 & 66.6 & 0.858 & 0.8180 & 0.0600 & 0.0700 \\
\hline Atherogenicity & $0.799^{\mathrm{A}}$ & $0.814^{\mathrm{A}}$ & $0.798^{\mathrm{A}}$ & $0.722^{\mathrm{B}}$ & $0.696^{\mathrm{B}}$ & $0.702^{\mathrm{B}}$ & 0.018 & $<0.0001$ & 0.8670 & 0.5740 \\
\hline
\end{tabular}

$\mathrm{CO}=$ control diet; $\mathrm{PF}=$ diet with addition of fat protected; $\mathrm{SG}=$ diet with addition of soybean grain .

Means followed by different lower and uppercase letters indicate significant differences within diets and between finishing systems, respectively $(P<0.05)$.

When there was interaction between diet and FS, only lowercase letters in comparison between all diets were taken into account.

Index $\Delta^{9}$ - desaturase $\mathrm{C} 16=100 *[\mathrm{C} 16: 1 n 9 /(\mathrm{C} 16: 0+\mathrm{C} 16: 1 n 9)]$.

Index $\Delta^{9}$ - desaturase $\mathrm{C} 18=100 *[\mathrm{C} 18: 1 n 9 /(\mathrm{C} 18: 0+\mathrm{C} 18: 1 n 9)]$.

Elongase $=100[(C 18: 0+C 18: 1$ cis-9) $/(C 16: 0+C 16: 1$ cis-9 $+C 18: 0+C 18: 1$ cis-9) $]$

Index of atherogenicity $=[C 12: 0+4(14: 0)+C 16: 0 /(\Sigma S F A+\Sigma$ PUFA $)]$. 
the rumen (Demeyer and Doreau, 1999; French et al., 2000), and a higher level of MUFA in the meat of feedlot-finished animals may occur. Increasing concentrations of specific concentrates in the diet also reduces the retention time of ruminal particulates, facilitating their passage and thus rendering them less subject to ruminal biohydrogenation and increasing the proportion of FA absorbed with the same characteristics that were ingested (Harfoot and Hazlewood, 1997).

According to Raes et al. (2004), the use of vegetable oils or whole grains results in a limited increase of DHA in muscle tissue. Consequently, it can be concluded that DHA formation is metabolically regulated and cannot be substantially influenced by diet, at least when not provided. However, this finding contradicts our results because we observed that the finishing system significantly affected the deposition of these acids. In general, pasture-finished animals had increased concentrations of DPA, DHA, and EPA. This is due to the fact that forages contain a high proportion (40-75\%) of their total fatty acids as $\alpha$-linolenic acid (Scollan et al., 2014),which is the building block of the $n-3$ series of essential fatty acids and elongation and desaturation of $\alpha$-linolenic acid result in the synthesis of EPA and DHA. the impact of inclusion of pasture specifically in the ration of beef cattle on the fatty acid composition of beef has been reviewed (Daley et al., 2010; Morgan et al., 2012). The findings of the large number of studies now available are generally consistent. Thus, feeding fresh grass compared to concentrates results in higher concentrations of $n-3$ PUFA in muscle lipids, both in the triacylglycerol and phospholipid fractions.

The PUFA:SFA ratio is considered an index of the nutritional quality of meat. Although this variable was not affected by the finishing system and lipid supplementation when measured in muscle tissue, all treatments showed a ratio lower than 0.45 , which is suitable for human health (Department of Health, 1994).

Feeding systems with a high intake of dietary grains (i.e. feedlot) resulted in a high proportion of C18:1 n9,cis and C18:2 cis-9 cis-12 (n6), and significantly less C18:3 $n 6$ (n3), thus increasing the n6:n3 ratio, which is not desirable. Furthermore, the meat had a reduced concentration of CLA due to a decrease in bacterial biohydrogenation in the rumen. By contrast, forage-based feeding systems lead to an increase of n3 PUFAs, thereby decreasing the ratio with n6. The higher content of PUFAs from the diet, together with a higher ruminal biohydrogenation, generates high concentrations of CLA in the meat, which is beneficial to human health.

Regarding the n6:n3 FA ratio, the Department of Health (1994) recommends that for the maintenance of good health, this ratio must not exceed 4:1. In this study, this ratio showed a negative trend in both muscle and subcutaneous fat tissues in feedlot-finished animals fed with $\mathrm{PF}$, as it was higher than the suggested limit $(10.2$ and $11.9 \mathrm{~g} / 100 \mathrm{~g}$, respectively). By contrast, this effect was not observed in pasture-finished animals, in agreement with the results of previous studies, which reported an FA profile more suited for human health (French et al., 2000; Gatellier et al., 2005; Nuernberg et al., 2005).

The results obtained herein are in agreement with those of Realini et al. (2004) who concluded that the negative image of meat attributes, due to its SFA profile, can be overcome by pasture-finishing as this would lead to greater PUFA deposition and, consequently, could increase the consumption of beef. Thus, cattle raised in pasture, as is the case of Brazil, presents a healthier FA profile that should be explored in the future by the export industry through differentiated marketing and added value certification of the product, bringing benefits to exporters and producers.

\section{Conclusion}

Supplementing lipids to cattle finished on grazing pasture is a strategy to improve the FA composition of meat, especially to increase the amounts of PUFA and improve n6:n3 FA ratio.

\section{Conflict of interest}

The authors declare no conflict of interest.

\section{Acknowledgments}

The authors thank the São Paulo Research Foundation (FAPESP, grants \#2011/00060-8; \#2013/02418-2; \#2013/04758-5; \#2014/ 09033-1; \#2014/09814-3; and \#2016/08585-6) for providing financial support.

\section{References}

ABIEC, 2015. Brazilian Livestock \& Beef Industry. http://www.brazilianbeef.org.br Accessed October 2015.

Association of Official Analytical Chemists, 1990. Official Methods of Analysis, 15th ed. AOAC, Arlington, VA.

Bligh, E.G., Dyer, W.J., 1959. A rapid method of total lipid extraction and purification. Can. J. Biochem. Physiol. 37, 911-917.

Carvalho, I.P.C., Fiorentini, G., Berndt, A., Castagnino, P.S., Messana, J.D., Frighetto, R.T.S., Reis, R.A., Berchielli, T.T., 2016. Performance and methane emissions of Nellore steers grazing tropical pasture supplemented with lipid sources. R. Bras. Zootec. 45, 760-767.

Coppock, C.E., Wilks, D.L., 1991. Supplemental fat in high energy rations for lactating cows: effects on intake, digestion, milk yield, and composition. J. Anim. Sci. 69 , 3826-3837.

Daley, C.A., Abbott, A., Doyle, P.S., Nader, G.A., Larson, S., 2010. A review of fatty acid profiles and antioxidant content in grass-fed and grain-fed beef. Nutr. J. 9, 10.

Demeyer, D., Doreau, M., 1999. Target and procedures for altering ruminant meat and milk lipids. Proc. Nutr. Soc. 58, 593-607.

Department of Health, 1994. Report on Health and Social Subjects No. 46. Nutritional Aspects of Cardiovascular Disease. Her Majesty's Stationary Office (HMSO), London, UK.

Fiorentini, G., Carvalho, I.P.C., Messana, J.D., Castagnino, P.S., Berndt, A., Canesin, R.C., Frighetto, R.T.S., Berchielli, T.T., 2014. Effect of lipid sources with different fatty acid profiles on the intake, performance, and methane emissions of feedlot Nellore steers. J. Anim. Sci. 92, 1613-1620.

Fiorentini, G., Carvalho, I.P.C., Messana, J.D., Canesin, R.C., Castagnino, P.S., Lage, J.F., Arcuri, P.B., Berchielli, T.T., 2015a. Effect of lipid sources with different fatty acid profiles on intake, nutrient digestion and ruminal fermentation of feedlot Nellore steers. Asian Australas. J. Anim. Sci. 28, 1583-1591.

Fiorentini, G., Lage, J.F., Carvalho, I.P., Messana, J.D., Canesin, R.C., Reis, R.A. Berchielli, T.T., 2015b. Lipid sources with different fatty acid profile alters the fatty acid profile and quality of beef from confined Nellore steers. Asian Australas. J. Anim. Sci. 28, 976-986.

Folch, J., Lees, M., Stanley, G.H.S., 1957. A simple method for the isolation and purification of total lipids from animal tissues. J. Biol. Chem. 226, 497-509.

Freitas, A.K.d, Lobato, J.F., Cardoso, L.L., Tarouco, J.U., Vieira, R.M., Dillenburg, D.R., Castro, I., 2014. Nutritional composition of the meat of Hereford and Braford steers finished on pastures or in a feedlot in southern Brazil. Meat Sci. 96, 353-360.

French, P., O'Riordan, E.G., Monahan, F.J., Caffrey, P.F., Moloney, A.P., 2003. Fatty acid composition of intra-muscular triacylglycerols of steers fed autumn grass and concentrates. Livest. Prod. Sci. 81, 307-317.

French, P., Stanton, C., Lawless, F., O'Riordan, E.G., Monahan, F.J., Caffey, P.J., Moloney, A.P., 2000. Fatty acid composition, including conjugated linoleic acid, of intramuscular fat from steers offered grazed grass, grass silage or concentrate-based diets. J. Anim. Sci. 78, 2849-2855.

Gatellier, P., Mercier, Y., Juin, H., Renerre, M., 2005. Effect of finishing mode (pasture or mixed-diet) on lipid composition, colour stability and lipid oxidation in meat from Charolais cattle. Meat Sci. 69, 175-186.

Griinari, J.M., Bauman, D.E., Yurawecz, M.P., 1999. Biosynthesis of conjugated linoleic acid and its incorporation into meat and milk in ruminants. In: Mossoba, M.M., Kramer, J.K.G., Pariza, M.W., Nelson, G.J. (Eds.), Advances in Conjugated Linoleic Acid Research. AOCS Press, Champaign, IL, USA, pp. 180-200.

Harfoot, C.G., Hazlewood, G.P., 1997. Lipid metabolism in the rumen. In: Hobson, P.N., Stewart, C.S. (Eds.), The Ruminal Microbial Ecosystem. Chapman \& Hall, London, pp. 382-426.

Hess, B.W., Moss, G.E., Hule, D.C., 2008. A decade of developments in the area of fat supplementation research with beef cattle and sheep. J. Anim. Sci. 86, E188-E204.

ISO, 1978. Animal and vegetable fats and oils-Preparation of methyl esters of fatty acids. Method 5509, 1-6.

Jenkins, T.C., 1993. Lipid metabolism in the rumen. J. Dairy Sci. 76, 3851-3863.

Kramer, J.K.G., Fellner, V., Dugan, M.E.R., Sauer, F.D., Mossoba, M.M., Yurawecz, M.P., 1997. Evaluating acid and base catalysts in the methylation of milk and rumen fatty acids with special emphasis conjugated dieno and total trans fatty acids. Lipids 32 , 1219-1228.

Lobato, J.F.P., Freitas, A.K.d., Devincenzi, T., Cardoso, L.L., Tarouco, J.U., Vieira, R.M., Dillenburg, D.R., Castro, I., 2014. Brazilian beef produced on pastures: sustainable and healthy. Meat Sci. 98, 336-345.

Lopes, L.S., Ladeira, M.M., Neto, O.R.M., Ramos, E.M., Paulino, P.V.R., Chizzotti, M.L., Guerreiro, M.C., 2012. Chemical composition and of fatty acids of the muscle longissimus dorsi and backfat of Red Norte and young Nellore bulls. R. Bras. Zootec. 41, 
978-985.

Malau-Aduli, A.E.O., Siebert, B.D., Bottema, C.D.K., Pitchford, W.S., 1997. A comparison of the fatty acid composition of tryacilglycerols in adipose tissue from Limousin and Jersey cattle. Aust. J. Agric. Research 48, 715-722.

Marmer, W.N., Maxwell, R.J., Williams, J.E., 1984. Effects of dietary regimen and tissue site on bovine fatty acid profiles. J. Anim. Sci. 59, 109-121.

Mertens, D.R., 1994. Regulation of forage intake (Ed.) In: Fahey Jr.G.C. (Ed.), Forage quality, evaluation, and utilization. American Society of Agronomy, Crop Science Society of America, Soil Science Society of America, Madison, WI., pp. 450-493.

Millen, D.D., Pacheco, R.D., Arrigoni, M.D., Galyean, M.L., Vasconcelos, J.T., 2009. A snapshot of management practices and nutritional recommendations used by feedlot nutritionists in Brazil. J. Anim. Sci. 87, 3427-3439.

Morgan, S., Huws, S.A., Scollan, N.D., 2012. Progress in forage-based strategies to improve the fatty acid composition of beef. Grassland Sci. Eur. 17, 295-307.

NRC, 2000. Nutrient requirements of beef cattle, 7th rev. ed. National Academy Press, Washington, DC.

Nuernberg, K., Dannenberger, D., Nuernberg, G., Ender, K., Voigt, J., Scollan, N.D., Wood, J.D., Nute, G.R., Richardson, R.I., 2005. Effect of a grass-based and a concentrate feeding systems on meat quality characteristics and fatty acid composition of longissimus muscle in different cattle breeds. Livest. Prod. Sci. 94, 137-147.

Oliveira, D.M., Ladeira, M.M., Chizzotti, M.L., Machato Neto, O.R., Ramos, E.M., Gonçalves, T.M., Bassi, M.S., Lanna, D.P., Ribeiro, J.S., 2011. Fatty acid profile and qualitative characteristics of meat from Zebu steers fed with different oilseeds. J. Anim. Sci. 89, 2546-2555.

Oliveira, E.A., Sampaio, A.A.M., Henrique, W., Pivaro, T.M., Rosa, B.L., Fernandes, A.R.M., Andrade, A.T., 2012. Quality traits and lipid composition of meat from Nellore young bulls fed with different oils either protected or unprotected from rumen degradation. Meat Sci. 90, 28-35.

Pariza, M.W., Park, Y., Cook, M.E., 2001. The biologically active isomers of conjugated linoleic acid. Prog. Lipid Res. 40, 283-298.

Poulson, C.S., Dhiman, T.R., Ure, A.L., Cornforth, D., Olson, K.C., 2004. Conjugated linoleic acid content of beef from cattle fed diets containing high grain, CLA, or raised on forages. Livest. Prod. Sci. 117-128.

Raes, K., De Smet, S., Demeyer, D., 2004. Effect of dietary fatty acids on incorporation of long chain polyunsaturated fatty acids and conjugated linoleic acid in lamb, beef and pork meat: a review. Anim. Feed Sci. Technol. 113, 199-221.

Realini, C.E., Duckett, S.K., Brito, G.W., Dalla Rizza, M., De Mattos, D., 2004. Effect of pasture vs. concentrate feeding with or without antioxidants on carcass characteristics, fatty acid composition, and quality of Uruguayan beef. Meat Sci. 66, 567-577.

Santos, R.D., Gagliardi, A.C.M., Xavier, H.T., 2013. Sociedade Brasileira de Cardiologia. I Diretriz sobre o consumo de Gorduras e Saúde Cardiovascular. Arq. Brasil. Cardiol. $100,1-40$.

Santos, S.A., Valadares Filho, S.C., Detmann, E., Valadares, R.F.D., Ruas, J.R.M., Amaral, P.M., 2011. Different forage sources for F1 Holstein $\times$ Gir dairy cows. Livest. Sci. $142,48-58$.

Scollan, N.D., Dannenberger, D., Nuernberg, K., Richardson, I., Mackintosh, S., Hocquette, J.F., Moloney, A.P., 2014. Enhancing the nutritional and health value of beef lipids and their relationship with meat quality. Meat Sci. 7, 384-394.

Ulbricht, T.L.V., Southgate, D.A.T., 1991. Coronary heart disease: seven dietary factors. Lancet 338, 985-992.

Van Soest, P.J., Robertson, J.B., Lewis, B.A., 1991. Methods for dietary fiber, neutral detergent fiber and nonstarch polysaccharides in relation to animal nutrition. J. Dairy Sci. 74, 3583-3597.

Varela, A., Oliete, B., Moreno, T., Portela, C., Monserrrat, L., Carballo, J.A., Sánchez, L., 2004. Effect of pasture finishing on the meat characteristics and intramuscular fatty acid profile of steers of the Rubia Gallega breed. Meat Sci. 67, 515-522.

Wood, J.D., Richardson, R.I., Nute, G.R., Fisher, A.V., Campo, M.M., Kasapidou, E., Sheard, P.R., Enser, M., 2003. Effects of fatty acids on meat quality: a review. Meat Sci. $66,21-32$.

Zinn, R.A., Gulati, S.K., Plascencia, A., Salinas, J., 2000. Influence of ruminal biohydrogenation on the feeding value of fat in finishing diets for feedlot cattle. J. Anim. Sci. $78,1738-1746$. 